\begin{tabular}{|c|c|c|}
\hline Postgraduate Bosowa University Publishing (PBUP) & INDONESIAN \\
JOURNAL
\end{tabular}

\title{
PENGARUH GAYA KEPEMIMPINAN, DISIPLIN KERJA DAN PELATIHAN TERHADAP KINERJA PEGAWAI DINAS KOMUNIKASI, INFORMATIKA DAN PERSANDIAN KABUPATEN DEIYAI
}

\author{
The Influence of Leadership Style, Work Discipline and Training on Employee Performance in \\ Communication, Information and Coding Department of Deiyai Regency \\ Robi Edowai ${ }^{1}$, Hasanuddin Remmang ${ }^{2}$, Miah Said ${ }^{2}$ \\ ${ }^{1}$ Bappeda Kabupaten Deiyai \\ ${ }^{2}$ Program Studi Manajemen Program Pascasarjana Universitas Bosowa \\ Email: amoyedowai119@gmail.com
}

Diterima: 12 Agustus 2020 /Disetujui: 07 Desember 2020

\begin{abstract}
ABSTRAK
Masalah sumber daya manusia masih menjadi sorotan bagi organisasi untuk tetap dapat bertahan di era globalisasi. Sumber daya manusia mempunyai peran utama dalam setiap kegiatan organisasi. Walaupun didukung dengan sarana dan prasarana serta sumber dana yang berlebihan, tetapi tanpa dukungan sumber daya manusia yang andal, maka kegiatan organisasi tidak akan terselesaikan dengan baik. Tujuan penelitian ini adalah untuk menganalisis sejauh mana pengaruh gaya kepemimpinan, disiplin kerja dan pelatihan terhadap kinerja pegawai, serta untuk menganalisis sejauh mana pengaruh gaya kepemimpinan, disiplin kerja dan pelatihan secara simultan terhadap kinerja pegawai. Teknik pengumpulan data melalui observasi, kuesioner dan dokumentasi, dengan teknik analisis data menggunakan uji instrument penelitian, uji asumsi klasik, analisis regresi berganda serta pengujian hipotesis. Hasil penelitian menemukan bahwa gaya kepemimpinan, disiplin kerja dan pelatihan mempunyai pengaruh yang positif dan signifikan terhadap kinerja pegawai. Berdasarkan hasil analisis koefisien korelasi maka dapat disimpulkan bahwa gaya kepemimpinan, disiplin kerja dan pelatihan mempunyai pengaruh secara serempak atau bersama-sama terhadap kinerja pegawai pada Dinas Komunikasi, Informatika dan Persandian Kabupaten Deiyai.
\end{abstract}

Kata Kunci: Gaya Kepemimpinan, Disiplin Kerja, Pelatihan dan Kinerja Pegawai, Deiyai

\begin{abstract}
The issue of human resources is still in the spotlight for organizations to remain viable in the era of globalization. Human resources play a major role in every organization's activities. Although supported by facilities and infrastructure as well as excessive sources of funds, without the support of reliable human resources, the activities of the organization will not be completed properly. The purpose of this study was to analyze the extent to which the influence of leadership style, work discipline and training on employee performance, as well as to analyze the extent to which the influence of leadership style, work discipline and training simultaneously on the performance of employees. Data collection techniques are through observation, questionnaires and documentation, with data analysis techniques using the research instrument test, classic assumption test, multiple regression analysis and hypothesis testing. The results found that leadership style, work discipline and training have a positive and significant effect on employee performance. Based on the results of the correlation coefficient analysis, it can be concluded that the leadership style, work discipline and training have an influence simultaneously or jointly on improving employee performance in the Department of Communication, Information and coding of Deiyai Regency.
\end{abstract}

Keywords: Leadership style, Work Discipline, Training and Employee Performance, Deiyai 


\section{PENDAHULUAN}

Masalah sumber daya manusia masih menjadi sorotan bagi organisasi untuk tetap dapat bertahan di era globalisasi. Sumber daya manusia mempunyai peran utama dalam setiap kegiatan organisasi. Walaupun didukung dengan sarana dan prasarana serta sumber dana yang berlebihan, tetapi tanpa dukungan sumber daya manusia yang andal, maka kegiatan organisasi tidak akan terselesaikan dengan baik (Notoadmodjo, 2013). Hal ini menunjukkan bahwa sumber daya manusia merupakan kunci pokok yang harus diperhatikan dengan segala kebutuhannya. Sebagai kunci pokok, sumber daya manusia akan menentukan keberhasilan pelaksanaan kegiatan organisasi.

Sumber Daya Manusia (SDM) mempunyai posisi yang sangat penting dalam suatu organisasi mengingat kinerja organisasi sangat dipengaruhi oleh kualitas sumber daya manusianya. Itulah sebabnya organisasi harus terus menerus mengembangkan sumber daya manusia yang dimiliki. SDM yang baik dilakukan suatu organisasi adalah SDM yang memenuhi kinerja yang baik, maju mundurnya sebuah organisasi tergantung dari kinerja pegawai. Kinerja karyawan yang baik akan berdampak pada kinerja organisasi yang baik pula, jika kinerja organisasi baik maka akan mempermudah pencapaian tujuan organisasi. Rendahnya kinerja individu secara simultan akan berdampak langsung pada hasil bisnis organisasi. Jika hal itu tidak disikapi dengan tepat maka cepat atau lambat organisasi akan kehilangan daya saing dan pada akhirnya mengalami kemunduran atau bahkan kehancuran (Alim, 2018).

Kinerja merupakan suatu hal yang sangat penting dalam upaya untuk mencapai tujuannya. Menurut Rosyida (2013) bahwa kinerja pegawai atau performance sebagai hasil kinerja yang dapat dicapai oleh seseorang atau kelompok orang dalam suatu organisasi baik secara kualitatif maupun secara kuantitatif, sesuai dengan kewewenangan, tugas dan tanggung jawab masing-masing dalam upaya mencapai tujuan organisasi bersangkutan secara legal, tidak melanggar hukum dan sesuai dengan moral ataupun etika. Kinerja pegawai merupakan salah satu tolok ukur dari kinerja organisasi, sehingga dalam hal ini perlu selalu mengevaluasi prestasi kerja tersebut dalam rangka untuk mempertahankan atau meningkatkan kinerja organisasi dan sebaliknya prestasi kerja yang sudah baik harus dipertahankan atau bahkan selalu ditingkatkan (Sedarmayanti, 2017).

Salah satu hal yang perlu diperhatikan dalam peningkatan kinerja pegawai adalah masalah gaya kepemimpinan. Menurut Rivai, et al. (2014) bahwa gaya kepemimpinan adalah sekumpulan ciri yang digunakan pimpinan untuk mempengaruhi bawahan atau pegawai agar sasaran organisasi tercapai atau dengan kata lain dapat dikatakan bahwa gaya kepemimpinan adalah pola perilaku dan strategi yang disukai dan sering diterapkan oleh seorang pemimpin untuk mengarahkan bawahannya agar mau mengikuti keinginan pemimpinnya. Ini menunjukkan bahwa keberhasilan atau kegagalan yang dialami sebagian besar organisasi ditentukan oleh kualitas kepemimpinan yang dimiliki oleh orang-orang yang diserahi tugas memimpin organisasi tersebut (Gulam et.al, 2019).

Peran kepemimpinan dalam suatu organisasi sangat besar, sehingga seorang pemimpin diharapkan mempunyai kemampuan memimpin yang dapat dihandalkan agar tujuan organisasi dapat tercapai. Demikian berpengaruhnya kepemimpinan dalam suatu organisasi sehingga biasa dikatakan bahwa kepemimpinan adalah merupakan faktor penentu berhasil tidaknya suatu organisasi dalam mencapai tujuan organisasi sebagaimana diharapkan (Sujudi, 2010). Penelitian Noor (2015) dan Saputra (2018) hasil penelitian menunjukkan bahwa gaya kepemimpinan mempunyai pengaruh yang positif dan signifikan terhadap kinerja pegawai.

Kemudian disiplin kerja juga dianggap sangat penting pengaruhnya dalam meningkatkan kinerja pegawai, sebagaimana dikemukakan oleh Ardana, et al.. (2013) bahwa disiplin kerja sebagai suatu sikap menghormati, menghargai, patuh, dan taat terhadap peraturan-peraturan yang berlaku, baik yang tertulis maupun tidak tertulis serta sanggup menjalankannya dan tidak mengelak untuk menerima sanksi-sanksinya. Ini menunjukkan bahwa kedisiplinan kerja yang ditanamkan kepada pegawai akan sangat mempengaruhi kesungguhan pegawai dalam bekerja, pegawai yang mempunyai tingkat kedisiplinan yang tinggi akan tetap bekerja dengan baik walaupun tanpa diawasi oleh atasan. Sikap untuk mematuhi dan melaksanakan tugas dengan penuh kesadaran dan tanggung jawab merupakan kunci pokok dalam rangka memegang teguh disiplin (Evanita, 2013).

Pegawai yang memiliki disiplin kerja yang baik yaitu disiplin terhadap waktu, prosedur kerja, dan disiplin terhadap segala sesutau yang berhubungan dengan pemanfaatan sarana dan prasarana pekerjaan. Jika pegawai tersebut sadar akan tugas dan tanggung jawabnya dan melakukan apa yang harus dilaksanakan sesuai aturan tata tertib yang berlaku, maka sangat berpengaruh terhadap kinerja pegawai yang bersangkutan. Semakin tinggi kesadaran akan tugas dan tanggung jawabnya dan semakin patuh terhadap peraturan atau tata tertib maka diharapkan akan menumbuhkan semangat kerja dan gairah kerja, sehingga menciptakan kinerja yang lebih baik. Penelitian Arifudin (2017) dan Wiratama et al. (2013) menemukan bahwa disiplin kerja berpengaruh positif terhadap kinerja pegawai.

Selain kepemimpinan dan disiplin kerja, maka pelatihan berpengaruh pula terhadap kinerja pegawai, hal ini senada dengan pendapat yang dikemukakan oleh Sudaryono, et al. (2018) bahwa pelatihan merupakan pendidikan jangka pendek yang biasanya lebih fokus pada praktik yang berguna untuk meningkatkan kinerja para karyawan dan untuk mengurangi kesalahan dalam pekerjaan. Pelatihan lebih ditekankan pada peningkatan kemampuan untuk melakukan pekerjaan yang spesifik pada saat ini. Pelatihan dan kinerja mempunyai hubungan yang sangat erat karena untuk dapat mencapai kinerja yang tinggi sangat ditentukan oleh adanya kemampuan dan 
keterampilan serta pengetahuan pegawai yang tinggi pula dari hasil pelatihan.

Pelatihan merupakan bagian dari pengembangan pegawai dalam suatu organisasi. Hal ini dikarenakan pelaksanaannya nanti akan menguntungkan individu pegawai khususnya dan organisasi pada umumnya. Sehingga nantinya pegawai akan mampu melaksanakan tugas-tugas yang diberikan. Pelatihan dapat meningkatkan kinerja seorang pegawai baik dalam penanganan pekerjaan yang ada saat ini maupun pekerjaan yang ada pada masa yang akan datang sesuai bidang tugas yang diemban dalam organisasi. Primajaya (2010) menemukan bukti empiris bahwa pelatihan berpengaruh positif terhadap kinerja pegawai, begitu pula dengan Munir, et al. (2019) dimana hasil temuan bahwa pelatihan berpengaruh terhadap kinerja pegawai.

Dinas Komunikasi, Informatika dan Persandian adalah salah satu instansi yang bergerak di bidang pelayanan publik yang dapat memberikan informasi tentang Kabupaten dan berada di bawah naungan Pemerintah Daerah Kabupaten Deiyai Propinsi Papua yang memiliki tugas untuk tetap mampu meningkatkan pelayanan yang lebih bermutu dan terjangkau oleh masyarakat agar dapat mewujudkan informasi yang lebih akurat meskipun dengan banyak keterbatasan. Sehingga dengan luasnya ruang lingkup organisasi maka perlu dituntut kinerja kerja yang tinggi dari masing-masing pegawai.

Berdasarkan pengamatan yang dilakukan pada Dinas Komunikasi, Informatika dan Persandian Kabupaten Deiyai Provinsi Papua, nampak permasalahan yang terjadi dilihat dari gaya kepemimpinan, dimana pemimpin kurang tegas dan tidak memberikan support bagi pegawainya. Kemudian permasalahan ditinjau dari disiplin kerja, dimana sebagian pegawai menunjukkan disiplin kerja rendah, hal ini dapat dilihat dari tingkat absensi, pegawai tidak mengikuti apel pagi, pegawai sering datang terlambat serta pulang lebih cepat. Menurut observasi dan informasi yang didapatkan dari kepala Sub Bagian Kepegawaian masih ditemukan pegawai tidak mengisi absensi sesuai yang seharusnya, kemudian masih adanya pegawai yang santai pada jam kerja, tidak adanya sanksi yang tegas. Sedangkan permasalahan ditinjau dari pelatihan bahwa rata-rata pegawai mengeluhkan bahwa pelatihan dilakukan tidak merata antara sesama pegawai, serta kurangnya frekunesi pelatihan, sehingga hal ini menunjukkan masih rendahnya kinerja sebagian pegawai yang bekerja pada Dinas Komunikasi, Informatika dan Persandian Kabupaten Deiyai.

\section{METODE PENELITIAN}

\subsection{Jenis Penelitian}

Rancangan penelitian yang digunakan adalah desain deskriptif analitik kuantitatif yang bertujuan menguraikan sifat dan karakteristik data-data atau variabel yang akan diujikan. Selain itu, desain penelitian ini digunakan untuk mendeskripsikan dan menggambarkan apa adanya mengenai suatu variabel, gejala, keadaan, atau fenomena tertentu, sehingga dalam penelitian ini digunakan untuk menganalisis data yang diperoleh secara mendalam dengan harapan dapat diketahuinya pengaruh antara variabel bebas terhadap variabel terikat. Dalam hal ini variabel yang akan diuji adalah variabel bebas pertama (X1) Gaya Kepemimpinan, variabel bebas kedua (X2) Disiplin Kerja, variabel bebas ketiga (X3) Pelatihan, dan variabel terikat (Y) Kinerja Karyawan. Penelitian ini juga mengunakan desain kausal yang bertujuan untuk menganalisa hubungan atau tingkat pengaruh variabel bebas terhadap bariabel terikat, apakah hubungan cukup signifikan melalui uji regresi. Dalam penelitian ini data yang diperoleh dianalisis secara statistik menggunakan software SPSS 23.

\subsection{Lokasi Penelitian}

Penelitian ini dilaksanakan di Dinas Komunikasi, Informatika dan Persandian Kabupaten Deiyai, yang beralamat di Jl. Utama Waghete, Kecamatan Tigi Kabupaten Deiyai.

\subsection{Populasi dan Sampel}

Populasi penelitian ini adalah seluruh pegawai Dinas Komunikasi, Informatika dan Persandian Kabupaten Deiyai yang berjumlah 54 orang. Sampel adalah seluruh pegawai Dinas Komunikasi, Informatika dan Persandian Kabupaten Deiyai. Pada penelitian ini jumlah populasi relatif sedikit sehingga mengunakan metode sensus (sampel jenuh) untuk menentukan sampel penelitian, dimana semua populasi di anggap sebagai sampel.

\subsection{Variabel Penelitian}

Dalam penelitian ini maka variabel yang digunakan adalah variabel independen dan variabel dependen. Variabel independen adalah variabel yang mempengaruhi Atau menjadi sebab perubahannya atau timbulnya Variabel depanden/terikat (Sugiyono, 2016). adalah Gaya kepemimpinan $\left(\mathrm{X}_{1}\right)$, disiplin kerja $\left(\mathrm{X}_{2}\right)$ dan pelatihan $\left(\mathrm{X}_{3}\right)$. Sedangkan variabel dependen merupakan variabel yang dipengaruhi atau menjadi akibat, karena adanya variabel bebas (Sugiyono, 2016). Variabel dependen dalam penelitian ini adalah kinerja pegawai (Y)

\subsection{Teknik Pengumpulan Data}

Teknik pengumpulan data yang digunakan dalam penelitian ini berupa data primer yang diperoleh dari hasil tanggapan responden atas daftar pernyataan berupa kuesioner yang disebarkan kepada responden. Kuesioner merupakan suatu teknik pengumpulan data dengan memberikan atau menyebarkan daftar pertanyaan kepada responden dengan harapan memberikan respon atas daftar pertanyaan tersebut. Sugiyono (2016). Daftar pertanyaan kuesioner yang digunakan bersifat terbuka. Bersifat terbuka artinya alternatif-alternatif jawaban telah disediakan, dalam hal ini responden hanya menjawab dengan cara memberi tanda tertentu pada alternatif jawaban yang disediakan. Kuesioner diberikan kepada responden secara langsung atau melalui email karena luasnya lingkup penelitian.

\subsection{Jenis dan Sumber Data}

Jenis data yang digunakan adalah: a. Data kualitatif yaitu data yang diperoleh berupa keterangan-keterangan tertulis yang mendukung penelitian ini, serta b. Data kuantitatif yaitu data yang berupa angka-angka yang dapat 
dihitung, serta data-data numerik lainnya baik yang telah diolah maupun belum diolah.

Sedangkan sumber data terbagi atas dua yakni: a. Data primer yaitu data yang diperoleh secara langsung dari objek penelitian. Data primer yang diperoleh berdasarkan jawaban responden terhadap kuesioner yang telah disebarkan yang dianggap mempunyai keterkaitan dengan data yang diperlukan, serta $b$. Data sekunder yaitu data yang diperoleh secara tidak langsung atau dikumpulkan dari sumber lain, seperti dari buku-buku, jurnal pendukung yang berhubungan dengan penelitian serta data lainnya yang dapat mendukung pokok pembahasan.

\subsection{Teknis Analisis Data}

Dari data hasil penelitian yang dikumpulkan, selanjutnya dilakukan analisis terhadap masalah yang dihadapi dengan menggunakan metode analisis dibawah ini:

1. Analisis kualitatif yakni suatu analisis yang menguraikan atau menggambarkan persepsi gaya kepemimpinan, disiplin dan pelatihan terhadap kinerja pegawai.

2. Analisis kuantitatif dengan metode analisis regresi berganda yakni suatu analisis untuk menganalisis pengaruh gaya kepemimpinan, disiplin dan pelatihan terhadap kinerja pegawai, dengan menggunakan rumus dikemukakan oleh Sugiyono (2016) sebagai berikut:

$$
\begin{array}{cl}
\text { Dimana: } & \mathrm{Y}=\beta_{0}+\beta_{1} \mathrm{X}_{1}+\beta_{2} \mathrm{X}_{2}+\beta_{3} \mathrm{X}_{3}+\varepsilon \\
\mathrm{Y} & =\text { Kinerja pegawai } \\
\mathrm{X}_{1} & =\text { Gaya kepemimpinan } \\
\mathrm{X}_{2} & =\text { Disiplin } \\
\mathrm{X}_{3} & =\text { Pelatihan } \\
\beta_{0} & =\text { Intercept/nilai constant } \\
\beta_{1-} \beta_{3} & =\text { Koefisien regresi } \\
\mathrm{e} & =\text { Standar error }
\end{array}
$$

3. Uji instrumen penelitian

a) Uji validitas adalah pengujian yang digunakan untuk mengukur sah atau valid tidaknya suatu kuesioner. Uji validitas dilakukan dengan melakukan korelasi bivariate antara masingmasing skor indikator dengan total skor variabel, dengan syarat sah atau validnya suatu item pertanyaan apabila memiliki nilai korelasi di atas dari 0,30 .

b) Uji reliabilitas dimaksudkan untuk mengukur suatu kuesioner yang merupakan indikator dari variabel. Reliabilitas diukur dengan uji statistik cronbach's alpha $(\alpha)$. Suatu variabel dikatakan reliabel jika memberikan nilai cronbach' alpha > 0,60 .

4. Uji Asumsi Klasik

Uji asumsi klasik diuji sebelum melakukan pengujian hipotesis untuk mendeteksi ada atau tidaknya penyimpangan. Uji asumsi klasik dalam penelitian terdiri atas uji normalitas, uji multikolineritas dan uji heterokes-dastisitas yang dapat diuraikan sebagai berikut: a. Uji Normalitas

Ghozali (2018) menyebutkan bahwa uji normalitas bertujuan untuk menguji apakah model regresi, variabel pengganggu atau residual memiliki distribusi normal. Cara untuk melihat normalitas dengan menggunakan metode Kolmogorov-Smirnov Test.

b. Uji Multikolinearitas

Multikolinieritas merupakan pengujian untuk menentukan apakah pada model regresi ditemukan adanya masalah di antara variabel independen. Batas dari tolerance value adalah 0,10 dan batas VIF adalah 10. Apabila hasil analisis menunjukkan hasil VIF di bawah nilai 10 dan tolerance value $\mathrm{di}$ atas 0,10 , maka tidak terjadi multikolinieritas, Ghozali (2018).

c. Uji Heteroskedastisitas

Uji heteroskedastisitas dilakukan untuk menguji apakah dalam sebuah model regresi terjadi ketidaksamaan varian residual dari suatu pengamatan ke pengamatan yang lain. Jika varian dari satu pengamatan ke pengamatan yang lain tetap, maka hal tersebut dinamakan homokedastisitas. Sedangkan jika variannya berbeda disebut heterokedastisitas. Model regresi yang baik adalah jika tidak terjadi heterokedastisitas.

5. Pengujian hipotesis

a. Uji parsial (Uji T) yang bertujuan untuk mengetahui apakah pengaruh masing-masing variabel bebas terhadap variabel terikat bermakna atau tidak. Hipotesis yang akan diuji adalah sebagai berikut:

1) $\mathrm{H}_{0}:$ bi $=0$, maka $X_{1}, X_{2}$ tidak berpengaruh terhadap $\mathrm{Y}$

2) $\mathrm{H}_{\mathrm{a}}$ : bi $\neq 0$, maka $\mathrm{X}_{1}, \mathrm{X}_{2}$ berpengaruh terhadap Y

Kriteria pengujian:

- Jika nilai signifikasi > 0,05, berarti tidak ada pengaruh antara variabel bebas terhadap variabel terikat.

- Jika nilai signifikasi < 0,05, berarti ada pengaruh antara variabel bebas terhadap variabel terikat.

b. Uji serempak (Uji F) yang bertujuan untuk mengetahui apakah seluruh variabel bebasnya secara bersama-sama mempunyai pengaruh yang bermakna terhadap variabel terikat. Dimana $F_{\text {hitung }}$ $>\mathrm{F}_{\text {tabel }}$, maka $\mathrm{H} 1$ diterima atau secara bersamasama variabel bebas dapat menerangkan variabel terikatnya secara serentak. Sebaliknya apabila $\mathrm{F}_{\text {hitung }}<\mathrm{F}_{\text {tabel}}$, maka Ho diterima atau secara bersama-sama variabel bebas tidak memiliki pengaruh terhadap variabel terikat. Untuk mengetahui signifikan atau tidak secara bersamasama varibel bebas terhadap variabel terikat digunakan probability secara $5 \%(\mathrm{a}=0,05)$.

- Jika sig > a $(0,05)$, Maka Ho diterima $\mathrm{H}_{1}$ ditolak. 
- Jika sig < a $(0,05)$, maka Ho ditolak $\mathrm{H}_{1}$ diterima.

6. Pengujian Koefisien Determinan $\left(\mathrm{R}^{2}\right)$

Koefisien determinan $\left(\mathrm{R}^{2}\right)$ dimaksudkan untuk mengetahui seberapa jauh kemampuan model dalam menerangkan variasi variabel dependen, dimana hal yang ditunjukan oleh besarnya koefisien determinasi $\left(\mathrm{R}^{2}\right)$ antara 0 (nol) dan 1 (satu). Koefisien determinasi $\left(\mathrm{R}^{2}\right)$ nol variabel independen sama sekali tidak berpengaruh terhadap variabel dependen. Apabila koefisien determinasi semakin mendekati satu, maka dapat dikatakan bahwa variabel independen berpengaruh terhadap variabel dependen. (Ghozali 2018:59).

\section{HASIL DAN PEMBAHASAN}

Untuk mengetahui adanya pengaruh positif atau negatif antara dua atau lebih variabel bebas dalam kaitannya dengan variabel terikat, dalam hal ini adalah pengaruh gaya kepemimpinan, disiplin kerja dan pelatihan terhadap Kinerja Pegawai pada Dinas Komunikasi, Informatika dan Persandian Kabupaten Deiyai, maka digunakan teknik analisis regresi linear berganda yang diolah dengan menggunakan sistem komputerisasi program SPSS release 24. Berikut ini disajikan hasil perhitungan regresi linear berganda seperti terlihat pada tabel berikut ini:

Tabel 1. Hasil Perhitungan Regresi Linear Berganda

\begin{tabular}{|c|c|c|c|c|c|}
\hline \multirow[t]{2}{*}{ Model } & \multicolumn{2}{|c|}{$\begin{array}{c}\text { Unstandardized } \\
\text { Coefficients }\end{array}$} & $\begin{array}{l}\text { Standardized } \\
\text { Coefficients }\end{array}$ & \multirow[t]{2}{*}{$\mathrm{t}$} & \multirow[t]{2}{*}{ Sig. } \\
\hline & B & Std. Error & Beta & & \\
\hline 1 (Constant) & -.267 & 5.587 & & -.048 & .962 \\
\hline $\begin{array}{l}\text { Gaya } \\
\text { Kepemimpinan }\end{array}$ & .251 & .104 & .218 & 2.405 & .020 \\
\hline Disiplin Kerja & .462 & .101 & .430 & 4.564 & .000 \\
\hline Pelatihan & .418 & .081 & .486 & 5.156 & .000 \\
\hline
\end{tabular}

Tabel di atas menunjukkan suatu pengaruh antara gaya kepemimpinan $\left(\mathrm{X}_{1}\right)$, disiplin kerja $\left(\mathrm{X}_{2}\right)$, dan pelatihan $\left(\mathrm{X}_{3}\right)$ terhadap kinerja pegawai $(\mathrm{Y})$, dimana dari tabel coefficient tersebut dapat diperoleh suatu persamaan regresi linear berganda sebagai berikut : Y $=-0,267+$ $0,251+0,462+0,418$

Hasil persamaan regresi tersebut mempunyai arti atau penjelasan sebagai berikut: 1 . Koefisien regresi variabel gaya kepemimpinan $\left(\mathrm{X}_{1}\right)$ bernilai sebesar 0,251 , hal ini menunjukkan bahwa gaya kepemimpinan berpengaruh positif terhadap peningkatan kinerja pegawai pada Dinas Komunikasi, Informatika dan Persandian Kabupaten Deiyai. 2. Koefisien regresi variabel disiplin kerja $\left(\mathrm{X}_{2}\right)$ bernilai sebesar 0,462, hal ini menunjukkan bahwa disiplin kerja berpengaruh positif terhadap peningkatan kinerja pegawai pada Dinas Komunikasi, Informatika dan Persandian Kabupaten Deiyai. 3. Koefisien regresi variabel pelatihan $\left(\mathrm{X}_{3}\right)$ bernilai sebesar 0,418, hal ini menunjukkan bahwa pelatihan berpengaruh positif terhadap peningkatan kinerja pegawai pada Dinas Komunikasi, Informatika dan Persandian Kabupaten Deiyai.
Untuk mengetahui keeratan hubungan kuat atau tidaknya antara variabel bebas (gaya kepemimpinan, disiplin kerja dan pelatihan) terhadap variabel terikat (kinerja pegawai) pada Dinas Komunikasi, Informatika dan Persandian Kabupaten Deiyai maka diperoleh koefisien korelasi ( $\mathrm{R}$ square) sebesar 0,767, hal ini menunjukkan bahwa variabel bebas yakni gaya kepemimpinan, disiplin kerja dan pelatihan memiliki hubungan yang kuat terhadap variabel kinerja pegawai, alasannya karena nilai $\mathrm{R}=0,767$ atau sudah mendekati angka 1. Sedangkan koefisien determinasi (lihat adjusted Rsquare) sebesar 0.563. hal ini menunjukkan bahwa perubahan yang terjadi pada variabel terikat (kinerja pegawai) sebesar $56.3 \%$ disebabkan oleh variabel bebas secara bersama-sama dan sisanya sebesar $43,7 \%$ disebabkan oleh variabel lain diluar dari variabel bebas yang diteliti, seperti : lingkungan kerja, kompensasi, kompetensi dan lain sebagainya. Pengujian hipotesis dapat dilakukan dengan 2 cara pengujian yakni: uji $F$ (uji serempak) dan uji t (uji parsial) yang dapat diuraikan satu persatu sebagai berikut:

Uji F (Uji Serempak)

Uji $\mathrm{F}$ adalah untuk menguji sejauh mana pengaruh variabel gaya kepemimpinan, disiplin kerja dan pelatihan secara bersama-sama atau serempak terhadap kinerja pegawai. Pengujian ini dapat dilakukan dengan cara membandingkan antara nilai signifikan dengan nilai standar. Apabila ketiga variabel yang diteliti memiliki nilai sig. lebih kecil atau kurang dari 0,05 berarti memberikan pengaruh secara serempak. Hasil pengujian (uji f) dengan menggunakan program SPSS release 24, maka penulis dapat merangkum hasil perhitungan uji $\mathrm{F}$ yaitu hubungan antar variabel gaya kepemimpinan, disiplin kerja dan pelatihan terhadap kinerja pegawai pada Dinas Komunikasi, Informatika dan Persandian Kabupaten Deiyai, dimana memiliki nilai signifikan 0,000, karena nilai signifikan $<0.05$ sehingga dapat disimpulkan $\mathrm{H}_{0}$ ditolak dan $\mathrm{H}_{1}$ diterima yang berarti bahwa secara bersama-sama variabel gaya kepemimpinan, disiplin kerja dan pelatihan mempunyai pengaruh secara serempak terhadap peningkatan kinerja pegawai pada Dinas Komunikasi, Informatika dan Persandian Kabupaten Deiyai.

Uji t (Uji Parsial)

Uji parsial (uji t) bertujuan untuk menguji pengaruh masing-masing variabel yakni : gaya kepemimpinan, disiplin kerja dan pelatihan dalam kaitannya dengan kinerja pegawai pada Dinas Komunikasi, Informatika dan Persandian Kabupaten Deiyai. Untuk pengujia parsial dapat dilakukan dengan cara membandingkan antara nilai signifikan dengan nilai standar. Apabila nilai signifikan kurang atau lebih kecil dari nilai standar $(0,05)$ berarti memberikan pengaruh secara signifikan. Hasil pengujian parsial dapat dilihat melalui tabel berikut ini:

Tabel 2. Hasil Pengujian secara Parsial

\begin{tabular}{l|c|c|c}
\hline \multicolumn{1}{c|}{ Variabel Penelitian } & Nilai Sign. & Nilai Standar & Keputusan \\
\hline Gaya kepemimpinan & 0,020 & 0,05 & Signifikan \\
Disiplin kerja & 0,000 & 0,05 & Signifikan \\
Pelatihan & 0,000 & 0,05 & Signifikan \\
\hline Sumber: Analisa Data, 2020
\end{tabular}


Berdasarkan hasil pengujian secara parsial maka dapat diketahui bahwa:

1. Nilai signifikan variabel gaya kepemimpinan $\left(\mathrm{X}_{1}\right)$ adalah sebesar 0,020 lebih kecil dari 0,05 (0,020< 0,05), sehingga dapat disimpulkan bahwa gaya kepemimpinan mempunyai pengaruh yang signifikan secara parsial terhadap kinerja pegawai pada Dinas Komunikasi, Informatika dan Persandian Kabupaten Deiyai.

2. Nilai signifikan variabel disiplin kerja $\left(\mathrm{X}_{2}\right)$ adalah sebesar 0,000 lebih kecil dari 0,05 $(0,000<0,05)$, sehingga dapat disimpulkan bahwa disiplin krja mempunyai pengaruh yang signifikan secara parsial terhadap kinerja pegawai pada Dinas Komunikasi, Informatika dan Persandian Kabupaten Deiyai.

3. Nilai signifikan variabel pelatihan $\left(\mathrm{X}_{3}\right)$ adalah sebesar 0,034 lebih kecil dari $0,05(0,000<0,05)$, sehingga dapat disimpulkan bahwa pelatihan mempunyai pengaruh yang signifikan secara parsial terhadap kinerja pegawai pada Dinas Komunikasi, Informatika dan Persandian Kabupaten Deiyai.

Berdasarkan hasil analisis regresi linear berganda yang dilakukan dalam penelitian ini, maka dapat diketahui bahwa gaya kepemimpinan, disiplin kerja dan pelatihan mempunyai pengaruh yang signifikan secara parsial dan simultan terhadap kinerja pegawai pada Dinas Komunikasi, Informatika dan Persandian Kabupaten Deiyai. Oleh karena itu penjelasan mengenai rumusan masalah dan pengujian hipotesis akan diuraikan satu persatu sebagai berikut:

Pengaruh gaya kepemimpinan terhadap kinerja pegawai pada Dinas Komunikasi, Informatika dan Persandian Kabupaten Deiyai.

Hasil uji linear berganda menunjukkan bahwa variabel gaya kepemimpinan memiliki nilai signifikansi sebesar 0,020 sehingga dapat dikatakan bahwa gaya kepemimpinan mempunyai pengaruh yang signifikan terhadap kinerja pegawai pada Dinas Komunikasi, Informatika dan Persandian Kabupaten Deiyai. Hasil analisis yang diperoleh sejalan dengan teori yang dikemukakan oleh Rivai, et al. (2014) bahwa gaya kepemimpinan adalah sekumpulan ciri yang digunakan pimpinan untuk mempengaruhi bawahan atau pegawai agar sasaran organisasi tercapai. Atau dengan kata lain dapat dikatakan bahwa gaya kepemimpinan adalah pola perilaku dan strategi yang disukai dan sering diterapkan oleh seorang pemimpin untuk mengarahkan bawahannya agar mau mengikuti keinginan pemimpinnya. Ini berarti bahwa keberhasilan atau kegagalan yang dialami sebagian besar organisasi ditentukan oleh kualitas kepemimpinan yang dimiliki oleh orang-orang yang diserahi tugas memimpin organisasi tersebut.

Dari hasil penyebaran kuesioner maka diperoleh temuan empirik bahwa gaya kepemimpinan yang diterapkan pada Dinas Komunikasi, Informatika dan Persandian Kabupaten Deiyai sudah berjalan dengan baik. Juliansyah Noor (2015) menemukan bahwa gaya kepemimpinan berpengaruh positif dan signfikan terhadap kinerja pegawai di BPLH Kabupaten Karawang cukup baik, Disiplin Kerja di BPLH Kabupaten Karawang berada pada skala tinggi. Sedangkan penelitian yang dilakukan oleh peneliti menemukan bahwa gaya kepemimpinan mempunyai pengaruh yang positif dan signifikan terhadap kinerja pegawai pada Dinas Komunikasi, Informatika dan Persandian Kabupaten Deiyai. Sehingga dapat dikatakan bahwa penelitian ini mendukung dari penelitian sebelumnya.

Pengaruh disiplin kerja terhadap kinerja pegawai pada Dinas Komunikasi, Informatika dan Persandian Kabupaten Deiyai.

Berdasarkan hasil pengujian regresi linear berganda Nampak bahwa variabel disiplin kerja memiliki nilai signifikansi sebesar 0,000 sehingga dapat dikatakan bahwa disiplin kerja mempunyai pengaruh yang signifikan terhadap kinerja pegawai pada Dinas Komunikasi, Informatika dan Persandian Kabupaten Deiyai. Hal ini sesuai dengan pendapat yang dikemukakan oleh Ardana, et al.. (2013) bahwa disiplin kerja sebagai suatu sikap menghormati, menghargai, patuh, dan taat terhadap peraturan-peraturan yang berlaku, baik yang tertulis maupun tidak tertulis serta sanggup menjalankannya dan tidak mengelak untuk menerima sanksi-sanksinya. Ini menunjukkan bahwa kedisiplinan kerja yang ditanamkan kepada pegawai akan sangat mempengaruhi kesungguhan pegawai dalam bekerja, pegawai yang mempunyai tingkat kedisiplinan yang tinggi akan tetap bekerja dengan baik walaupun tanpa diawasi oleh atasan sehingga menghasilkan kinerja kerja yang tinggi pula.

Dari hasil penyebaran kuesioner kepada sejumlah responden yang menjadi sampel penelitian ini maka diperoleh temuan empirik bahwa disiplin kerja pada Dinas Komunikasi, Informatika dan Persandian Kabupaten Deiyai sudah berjalan dengan baik sehingga dapat meningkatkan kinerja kerja pegawai. Zainal Arifudin (2017) hasil penelitian menemukan bahwa disiplin kerja berpengaruh positif dan signifikan terhadap kinerja karyawan pada BPR Bank Daerah Kabupaten Kediri. Kemudian I Nyoman Jaka Alit Wiratama, et al. (2013) dimana hasil temuan bahwa disiplin kerja mempunyai pengaruh yang signifikan terhadap Kinerja Karyawan PDAM Tirta Mangutama Kabupaten Badung. Sedangkan hasil penelitian yang dilakukan oleh peneliti menemukan bahwa disiplin kerja berpengaruh positif dan signifikan terhadap kinerja pegawai pada Dinas Komunikasi, Informatika dan Persandian Kabupaten Deiyai. Sehingga dapat dikatakan bahwa penelitian ini sejalan dengan penelitian yang dilakukan oleh Zainal Arifudin (2017) dan I Nyoman Jaka Alit Wiratama, et al. (2013).

Pengaruh Pelatihan terhadap kinerja pegawai pada Dinas Komunikasi, Informatika dan Persandian Kabupaten Deiyai.

Hasil pengujian regresi linear berganda diperoleh nilai koefisien regresi untuk variabel pelatihan memiliki nilai signifikansi sebesar 0,000 sehingga dapat dikatakan bahwa pelatihan mempunyai pengaruh yang signifikan terhadap kinerja pegawai pada Dinas Komunikasi, Informatika dan Persandian Kabupaten Deiyai. Hal ini sesuai dengan teori yang dikemukakan Sudaryono, et al. 
(2018) bahwa pelatihan merupakan pendidikan jangka pendek yang biasanya lebih fokus pada praktik yang berguna untuk meningkatkan kinerja para karyawan dan untuk mengurangi kesalahan dalam pekerjaan. Pelatihan lebih ditekankan pada peningkatan kemampuan untuk melakukan pekerjaan yang spesifik pada saat ini. Pelatihan dan kinerja mempunyai hubungan yang sangat erat karena untuk dapat mencapai kinerja yang tinggi sangat ditentukan oleh adanya kemampuan dan keterampilan serta pengetahuan pegawai yang tinggi pula dari hasil pelatihan.

Berdasarkan penelitian yang dilakukan nampak diperoleh temuan-temuan bahwa materi pelatihan yang diberikan saat training, merupakan materi yang belum pernah diketahui sebelumnya. Materi pelatihan yang diberikan saat training, sesuai dengan tugas dan pekerjaansaya di lapangan. Metode pelatihan yang digunakan oleh Instruktur saat training, dapat dipahami karyawan. Kemudian metode pelatihan yang digunakan oleh Instruktur saat training, sesuai dengan job description karyawan. Instruktursaat training merupakan orang yang ahli di bidangnya, begitu pula bahwa Instruktur saat training sudah menguasai materi dan metode yang digunakan. Sarana pelatihan (buku, modul dan alat peraga) yang diberikan saat pelaksanaan training memadai.

Selanjutnya fasilitas pelatihan (ruangan, akomodasi, komsumsi dan uang saku) yang diberikan saat pelaksanaan training sesuai dengan standar, Kualifikasi Peserta training memenuhi ketentuan maupun persyaratan yang ditetapkan perusahaan, serta peserta pelatihan diberikan penugasan terkait evaluasi materi pelatihan.

Penelitian Primajaya (2010) menemukan bukti empiris bahwa pelatihan berpengaruh positif terhadap kinerja pegawai, begitu pula dengan penelitian yang dilakukan oleh Munir, et al. (2019) dimana hasil temuan bahwa pelatihan berpengaruh terhadap kinerja pegawai. Sedangkan penelitian yang dilakukan oleh peneliti bahwa pelatihan berpengaruh positif dan signifikan terhadap kinerja pegawai pada Dinas Komunikasi, Informatika dan Persandian Kabupaten Deiyai. Sehingga dapat dikatakan bahwa penelitian ini mendukung dari penelitian yang dilakukan oleh Primajaya (2010), dan Munir, et al. (2019).

\section{KESIMPULAN DAN SARAN}

Hasil penelitian dan pembahasan dapat disimpulkan bahwa gaya kepemimpinan mempunyai pengaruh yang positif dan signifikan terhadap kinerja pegawai pada Dinas Komunikasi, Informatika dan Persandian Kabupaten Deiyai. Gaya kepemimpinan, disiplin kerja dan pelatihan mempunyai pengaruh secara serempak atau bersama-sama terhadap peningkatan kinerja pegawai pada Dinas Komunikasi, Informatika dan Persandian Kabupaten Deiyai. Disarankan agar perlunya Pimpinan pada Dinas Komunikasi, Informatika dan Persandian Kabupaten Deiyai untuk lebih meningkatkan gaya kepemimpinan yang diterapkan selama ini, yakni dengan selalu memantau dan memonitoring setiap kegiatan atau aktivitas pekerjaan setiap pegawai.

\section{DAFTAR PUSTAKA}

Afandi, Pandi. 2018. Manajemen Sumber Daya Manusia: Teori, Konsep dan Indikator. Cetakan Pertama, Penerbit: Zanafa Publishing, Pekanbaru.

Alim, Syahrul. 2018. Studi Properti Psikometri Alat Ukur Performance Appraisal: Individual Work Performance Questionnaire (IWPQ). Etd.repository.ugm.ac.id/home/detail_pencarian/1577 84

Andi Abdul Munir, dkk (2019) Pengaruh Pelatihan, Disiplin dan Motivasi Terhadap Kinerja Pegawai Pada Badan Pengelolaan Keuangan dan Asset Daerah Provinsi Sulawesi Tengah. e Jurnal Katalogis, Volume 5 Nomor 3, Maret 2017 hlm 153-164 ISSN: 2302-2019

Ardana I Komang, 2013, Manajemen Sumber Daya Manusia, edisi pertama, cetakan pertama, Penerbit : Graha Ilmu, Jakarta

Bangun, Wilson. 2012. "Manajemen Sumber Daya Manusia" Penerbit: Erlangga. Jakarta

Darojat, Achmad. 2015. Konsep-Konsep Manajemen Personalia Masa Kini, cetakan pertama, penerbit: Refika Aditama, Bandung

Evanita, Leny (2013) disiplin kerja, gaya kepemimpinan, pelatihan dan kinerja karyawan rsud lubuk sikapin. Tesis Universitas Esa Unggul, Jakarta

Fahmi Irham. 2016. Manajemen Kepemimpinan: Teori \& Aplikasi. Edisi Revisi. Alfabeta. Bandung.

Ghozali, Imam. 2018. Aplikasi Analisis Multivariate dengan Program IBM SPSS 25. Badan Penerbit Universitas Diponegoro, Semarang

Gulam, R. A., Marjuni, S., \& Abduh, T. (2019). Pengaruh Motivasi, Pelatihan, Dan Disiplin Kerja Terhadap Kinerja Karyawan Pada Pt Nippon Indosari Corpindo, Tbk. Indonesian Journal of Business and Management, 1(2), 41-47.

Hardika Saputra (2018) engaruh Kepemimpinan dan Disiplin Kerja Terhadap Kinerja Pegawai Pada Rumah Sakit Penawar Medika Tulang Bawang Jurnal Iqtisad Volume 1, Nomor 2, Juli - Desember 2018 Fakultas Syariah IAI Agus Salim Metro Lampung LP3M IAI Agus Salim Lampung

I Nyoman Jaka Alit Wiratama, dkk (2013) Pengaruh Kepemimpinan, Diklat, dan Disiplin Kerja Terhadap Kinerja Karyawan PDAM Tirta Mangutama Kabupaten Badung. Jurnal Manajemen, Strategi Bisnis, dan Kewirausahaan Vol. 7, No. 2, Agustus 2013

Juliansyah Noor (2015) Pengaruh Kepemimpinan dan Disiplin Kerja Terhadap Kinerja Pegawai Badan Pengelolaan Lingkungan Hidup Kabupaten Karawang. Jurnal Ekonomi dan Bisnis STIE YPN Vol. VIII No. 3 Oktober 2015

Lubis Yusniar, dkk 2018. Manajemen Dan Riset, Sumber Daya Manusia, cetakan pertama, Penerbit: Alfabeta, Bandung

Prawirosentono, Suyadi. 2017. Manajemen Sumber Daya Manusia: Kebijakan Kinerja Karyawan. Edisi revisi. Cetakan Kedelapan. Penerbit: BPFE. Yogyakarta 
Rivai, Veithzal dan Sagala, Ella Jauvani, 2014, Manajemen Sumber Daya Manusia untuk Perusahaan dari teori ke Praktik, Penerbit: Raja Grafindo, Jakarta.

Sastrohadiwiryo, Siswanto, 2015, Manajemen Tenaga Kerja Indonesia, Pendekatan Administratif dan Operasional, cetakan pertama, Penerbit: Bumi Aksara, Jakarta

Sedarmayanti, 2017. Perencanaan dan Pengembangan Sumber Daya Manusia, Untuk Meningkatkan Kompetensi, Kinerja dan Produktivitas Kerja, cetakan pertama, Penerbit : Refika Aditama, Bandung

Sudaryono Yoyo, 2018. Manajemen Sumber Daya Manusia, edisi pertama, Penerbit: Andi Offset, Yogyakarta

Sugiyono. 2016. Statistik Untuk Penelitian. Cetakan Kedua Puluh Tujuh, Penerbit Alfabeta, Bandung.

Sujudi, Riyanto 2010. Pengaruh Kepemimpinan, Motivasi, Lingkungan Kerja, Disiplin Kerja dan Pengawasan Terhadap Kinerja Pegawai Dinas Perindustrian, Perdagangan, Penanaman Modal dan Koperasi Kabupaten Karanganyar, Jurnal Manajemen, Strategi Bisnis dan Kewirausahaan, Vol.7 No.2, Agustus 2010, Universitas Udayana, Bali

Suparyadi. 2015. Manajemen Sumber Daya Manusia, Menciptakan Keunggulan Bersaing Berbasis Kompetisi SDM. Penerbit : Andi Jakarta

Zainal Arifudin (2017) pengaruh kepemimpinan dan disiplin kerja terhadap kinerja karyawan pd bpr bank daerah kabupaten Kediri.. Jurnal Simki-Economic Vol. 01 No. 04 Tahun 2017 ISSN: BBBB-BBBB. Universitas Nusantara PGRI Kediri. 